\title{
Kontestasi Nilai-Nilai Asia dan Hak Asasi Manusia di Indonesia Tahun 1991-1999
}

\author{
Mahesti Hasanah $^{1}$
}

\begin{abstract}
Abstrak
Tulisan ini mendiskusikan tentang kontestasi nilai-nilai Asia dan penegakan norma HAM di Indonesia tahun 1991-1999 pada masa akhir pemerintahan Soeharto dan awal pasca Reformasi. Saat itu, para pemimpin ASEAN termasuk Indonesia, gencar menggaungkan nilai-nilai Asia. Nilai Asia pada masa Soeharto mengedepankan gotong-royong dan mendiskreditkan hak individu; serta membatasi kebebasan berpendapat dan berekspresi melalui program Pancasila (P4). Penelitian ini menunjukkan keterkaitan bagaimana rezim otoritarian menggunakan nilai-nilai Asia dan norma HAM untuk tujuan politik. Hak sipil dan politik menjadi dasar norma HAM yang didengungkan masyarakat sipil dan dunia internasional untuk menekan pemerintah Indonesia. Perkembangan HAM tidak bisa dipisahkan dari wacana demokrasi. Hal ini dikarenakan norma demokrasi merupakan bagian integral dari realisasi HAM. Dengan menggunakan kerangka teoretis pilihan rasional, artikel ini berargumen bahwa pemimpin Indonesia menggunakan nilai-nilai Asia dan norma HAM sebagai instrumen dan tujuan politik. Tujuan artikel ini untuk menginvestigasi karakter otoritas pemerintah Orde Baru menggunakan nilai-nilai Asia dan norma HAM sebagai instrumen politik. Dari sisi metodologi, penelitian ini melihat kembali kajian literatur yang berargumen jika norma bersifat konstruktivis dan mampu membentuk identitas dan memengaruhi perilaku aktor. Berbeda dengan studi yang ada, pendekatan rasional dalam tulisan ini memberikan alternatif lain untuk melihat pemaknaan norma dalam perkembangan HAM di Indonesia.
\end{abstract}

Kata kunci: Teori Pilihan Rasional; Hak Asasi Manusia; Nilai-Nilai ASIA; Hak Sipil dan Politik; Indonesia.

1 Asisten Peneliti di Research Centre for Politics and Government (PolGov), Departemen Politik dan Pemerintahan, FISIPOL, Universitas Gadjah Mada. 


\section{PENDAHULUAN}

Artikel ini bertujuan untuk melihat karakter penggunaan nilainilai Asia dan norma HAM yang digunakan oleh Presiden Soeharto pada tahun-tahun kritis 1991-1999. Soeharto diketahui bukan satusatunya pemimpin Asia yang menggunakan nilai-nilai Asia sebagai instrumen politiknya. Tahun 1990-an, para pemimpin ASEAN mewacanakan nilai-nilai Asia untuk menghalau arus norma HAM global. Nilai-nilai Asia dipengaruhi oleh ajaran Confucianism dari Asia Timur yang menjunjung tinggi harmoni sosial kesejahteraan bersama, loyal dan hormat kepada pemimpin, serta terbuka terhadap perubahan (Freeman, 1996).

Artikel ini berangkat dari minat untuk memperkaya studi tentang nilai-nilai Asia yang dikaitkan dengan perkembangan HAM pada tahun-tahun kritis 1990-an. Sekalipun saat ini perkembangan HAM telah memasuki era baru pasca demokratisasi, namun diskusi tentang nilai-nilai Asia dalam konteks tahun 1990-an tetap relevan untuk memahami salah satu hambatan bagi lambannya pembangunan HAM dan demokrasi di Indonesia. Seperti diketahui, perkembangan kualitas demokrasi Indonesia dalam beberapa tahun terakhir tampak menurun (lihat Power, 2018), termasuk dalam kaitannya dengan jaminan terhadap hak-hak dasar individu. Sementara, norma demokrasi merupakan bagian integral dari realisasi $\mathrm{HAM}^{2}$ (Eldridge, 2002). Robert Dahl (1989) berargumen bahwa nilai demokrasi bertumpu pada ide kesetaraan intrinsik individu. Dengan kata lain, hak individu menjadi salah satu kunci keberlangsungan demokrasi.

2 Artikel 21 dari International Convention on Civil and Political Rights (ICCPR) menjelaskan tentang kesetaraan setiap warga negara untuk berpartisipasi dalam kepentingan umum, baik secara langsung maupun melalui representasi mereka. Representasi merupakan kata kunci dari pelaksanaan demokrasi. Dengan demikian, diskusi tentang HAM tidak bisa dipisahkan dari wacana demokrasi. 
Sehubungan dengan itu, masyarakat Barat selama lebih dari 15 tahun secara konsisten mengkritisi pembangunan hak asasi manusia (HAM) dengan merujuk pada banyaknya pelanggaran hak sipil dan politik yang terjadi di negara-negara ASEAN (Katsumata, 2009). Penurunan ini tidak hanya berdampak terhadap partisipasi dalam demokrasi elektoral, tetapi juga mengancam kualitas norma-norma demokrasi lainnya, seperti transparansi dan akuntabilitas.

Bahasan mengenai nilai-nilai Asia, perkembangan norma HAM dan demokrasi di Indonesia biasanya diawali dari analisa dinamika regional di ASEAN sebelum mengaitkannya dengan dinamika di Indonesia (lihat Mautzy, 1997; Hsien-Li, 2011; dan Chan, 2000) meskipun ada juga studi yang fokus membahas HAM dan demokrasi secara khusus. Tulisan Eldridge (2002) secara kritis melihat perkembangan HAM di Indonesia pasca Soeharto, termasuk melihat institusionalisasi HAM di awal tahun 2000. Namun, kajian-kajian yang ada menempatkan nilainilai Asia dan norma HAM sebagai sesuatu yang bisa mengonstruksi perilaku pemerintah. Lebih jauh, terbatasnya kajian tentang pergolakan politik dan perkembangan HAM di Indonesia membuat pemahaman tentang logika pemerintah Orde Baru pada tahun-tahun itu pun terbatas. Melihat kesenjangan yang ada, tulisan ini juga bertujuan untuk menelisik kaitan nilai-nilai Asia dan norma HAM di Indonesia selama dekade terakhir pemerintahan Soeharto.

Dalam artikel ini, kaitan antara nilai-nilai Asia dan norma HAM pada masa Soeharto di Indonesia merujuk pada pembatasan kebebasan berpendapat, berekspresi, dan berserikat atau hak-hak sipil dan politik. Di luar penggunaan instrumen militer, pewacanaan nilainilai bangsa juga dilakukan secara masif. Di Indonesia, nilai-nilai Asia identik dengan nilai-nilai Pancasila yang salah satu prinsipnya adalah menjunjung gotong-royong (Vickers dan Fisher, 1999). Internalisasi nilai-nilai Pancasila dilakukan melalui banyak cara, termasuk dengan program Pedoman Penghayatan dan Pengalaman Pancasila (P4) yang 
diajarkan di sekolah, birokrasi pemerintahan, dan perguruan tinggi guna mendukung kepentingan politik rezim.

Lebih lanjut, diskusi tentang nilai-nilai Asia di Indonesia selama masa Soeharto pada umumnya terbagi menjadi tiga kelompok. Pertama, kaitan nilai-nilai Asia dengan demokrasi. Kelompok ini berpendapat jika nilai-nilai Asia menjadi salah satu tantangan demokrasi di ASEAN, termasuk di Indonesia (lihat Ulum dan Hamida, 2018; Asplund, 2009; Thompson, 2007). Kedua, nilai-nilai Asia dikaitkan dengan ekonomi, seperti korupsi dan wacana "Macan Asia" (Chong, 2002). Salah satu kajiannya datang dari Mollet (2018) yang berargumen jika nilai-nilai Asia sangat berperan terhadap proses korupsi, kolusi, dan nepotisme Soeharto pada waktu itu. Ketiga, kajian yang melihat hubungan pembentukan identitas dengan nilai-nilai Asia (Acharya, 2005; Jones dan Smith, 2007). Salah satu kajian ini bisa dilihat dalam tulisan Vickers dan Fisher (1999) yang melihat proses pembentukan identitas nasional di masa Orde Baru yang lebih dulu daripada wacana nilai-nilai Asia di ranah regional. Mereka menemukan pembentukan identitas nasional Indonesia yang bersifat sentralistik dan terstruktur. Secara umum, ketiga studi tersebut menganalisis bagaimana norma bisa mengonstruksi perilaku aktor atau disingkat sebagai kajian "norms and behavior". Hal ini bisa dilihat dari fokus kajian yang ada cenderung melihat bagaimana norma berdampak atau memengaruhi perilaku otoritas.

Studi-studi tersebut menunjukkan fokus terhadap konstruksi nilai dan norma lebih utama daripada fokus pada nilai dan norma sebagai sebuah komoditas politik. Sementara, investigasi dengan menggunakan teori pilihan rasional (rational choice theory) memberikan bukti empiris tentang adanya perbedaan sikap pemerintah pada saat merespons tuntutan perkembangan HAM pada level regional/internasional dengan pada saat merespons kejadian di dalam negeri. Secara teoretik, 
perbedaan sikap yang oleh Davies (2013) disebut sebagai actionidentitiy gap menjadi penting untuk dianalisis.

Berbeda dengan kecenderungan studi yang ada dan lebih melihat pada konstruksi nilai itu sendiri, artikel ini melihat nilai dan norma sebagai sebuah instrumen yang dapat digunakan oleh orang ataupun pemimpin. Dengan fokus terhadap motif atau tujuan pemimpin itu sendiri, tulisan ini menganalisis action-identity gap yang ada. Argumen tulisan ini berupa penggunaan nilai-nilai Asia dalam perdebatan norma HAM merupakan bagian dari strategi para pemimpin untuk mencapai tujuan politis mereka.

Artikel ini bertujuan mengusung rumusan masalah bagaimana karakter pemanfaatan nilai-nilai Asia dan norma HAM oleh pemimpin Indonesia pada tahun 199 -1999? Penelitian ini merupakan studi kualitatif dengan menggunakan metode penelitian studi pustaka, yaitu menggunakan studi-studi yang sudah ada sebagai sumber utamanya. Lebih khusus lagi, bahan yang digunakan adalah studi yang berkaitan dengan masa-masa akhir Orde Baru dan masa transisi tahun pertama setelah Reformasi.

\section{PENDEKATAN RASIONAL (RATIONAL CHOICE THEORY) SEBAGAI ALTERNATIF UNTUK MENJELASKAN PERDEBATAN HAM DI ASEAN}

Studi-studi tentang nilai-nilai Asia dengan pendekatan rasional muncul setelah kritik terhadap studi serupa yang fokus terhadap "norms and behavior". Salah satu kritik yang muncul menyoal ketidakmampuan pendekatan tersebut untuk menjelaskan mengapa negara-negara ASEAN menunjukkan perbedaan sikap (action-identitiy gap) dalam merespons tuntutan untuk komitmen terhadap pembangunan HAM di ranah regional dan nasional (Davies, 2013). 
Berkaitan dengan itu, para ilmuwan politik mencoba memetakan kepentingan negara berdasarkan identitasnya. Wendt (1994) membagi identitas sebuah negara menjadi dua, yakni identitas internal dan eksternal. Wendt (1994) mendefinisikan identitas internal, yaitu negara menjadi sebuah representasi konstitusi dari kepentingan komunitas sosial dan domestik yang ada di wilayah tertentu. Sementara itu, identitas eksternal adalah berkaitan dengan rekognisi negara oleh aktor atau komunitas internasional. Kebanyakan literatur melihat jika identitas eksternal sebuah negara di ranah regional merupakan interpretasi terhadap identitas internal negara tersebut di ranah nasional (Thomas, 2001). Namun, ada banyak faktor yang memengaruhi keduanya sehingga identitas regional tidak hanya dianggap sebagai dipengaruhi oleh identitas nasional, pun sebaliknya (Acharya, 2005; Jones dan Smith, 2007).

Beberapa akademisi menganalisis perdebatan HAM di ASEAN dari pendekatan rasional, yaitu melihat norma sebagai alat untuk mencapai tujuan tertentu. Davies (2013) secara apik menjelaskan bahwa penggunaan norma HAM di ASEAN semata-mata untuk mendukung kepentingan politik pemimpinnya. Davies (2013) menjelaskan bahwa action-identity gap terjadi karena pemimpin ASEAN termasuk Indonesia, menggunakan norma HAM sebagai konsekuensi logis untuk merespons tantangan yang ada dari dunia internasional dan dinamika internal masing-masing negara. Waktu dan karakter adopsi norma-norma HAM awalnya untuk menjaga stabilitas sosial dan krisis keuangan tahun 1997. Adapun Ravindra (1998) melihat kontestasi nilai-nilai Asia dengan universalitas sebagai alat untuk meningkatkan posisi tawar ASEAN terhadap negara-negara maju. Namun demikian, analisa yang ada masih melihat perdebatan HAM dari ranah identitas eksternal, yakni secara regional. Analisa mendalam terhadap jati diri nasional diperlukan guna menjelaskan perbedaan distorsi antara identitas internal dan eksternal penggunaan norma HAM di ASEAN. 
Lebih lanjut, pendekatan rasional menekankan analisanya terhadap proses pengambilan keputusan individual dari aktor negara (Kydd, 2008). Aktor diasumsikan memiliki preferensi terhadap berbagai hasil yang mungkin terjadi dalam situasi apa pun. Dengan demikian, ia cenderung memilih strategi atau tindakan apa pun yang memberikan kemungkinan hasil yang lebih baik (Kydd, 2008). Aktor cenderung menggunakan sumber daya yang ada untuk menginternalisasi suatu identitas maupun value atau nilai-nilai yang ingin dilembagakan ke tatanan sosial (Schimmelfennig dan Sdelmeier, 2005 dalam Davies 2012).

Dalam kaitannya dengan pemilihan dan penetapan nilai dan norma tertentu, termasuk nilai Asia dan norma HAM, pendekatan rasional melihat kembali sifat (nature) aktor dalam menggunakannya sebagai instrumen ini. Aktor menyelesaikan sebuah masalah secara rasional. Namun, tolok ukur terhadap rasionalitas bertentangan dengan kepentingan tetap (fixed interest) dan kepercayaan normatif tidak bisa menjelaskan perilaku tersebut (Kydd, 2008). Aktor cenderung berkepentingan untuk terus berupaya untuk memaksimalkan manfaat (utility maximization), dalam hal ini dengan cara selalu fokus terhadap kepentingannya terhadap kuasa, posisi, dan kedudukannya terhadap aktor lainnya (Davies, 2013).

Karena kepentingan-kepentingan tersebut, pendekatan rasional memahami aktor sebagai pihak yang memanfaatkan norma dalam rangka mencapai atau memaksimalkan manfaat dari norma tersebut (Davies, 2013). Norma, oleh karenanya dilihat sebagai alat untuk digunakan, memanipulasi, atau sesuatu yang ditinggalkan sebagai akibat dari perubahan nasib (Davies, 2013). Kemudian, Davies (2013) pun berargumen bahwa "para aktor hanya tertarik" untuk memaksimalkan semua sumber daya dan kapasitas, termasuk menggunakan norma sebagai alat, untuk mendukung dan mengamankan kepentingan politik pribadi mereka. Bila dikaitkan dengan hal itu, penggunaan nilai-nilai 
Asia dapat dibaca sebagai tak lebih dari wacana untuk melindungi pemerintahan yang opresif. Premis ini kontekstual dengan keadaan di ASEAN waktu itu (Freeman, 1996).

Untuk menganalisis sifat penggunaan norma HAM di Indonesia, tulisan ini menggunakan dua dimensi pendekatan rasional dari Davies (2013). Pertama, dimensi waktu. Dimensi waktu dalam tulisan ini fokus terhadap keadaan penggunaan norma HAM sebagai inisiatif sekaligus risiko untuk menyelamatkan kondisi Indonesia. Davies menjelaskan jika pemanfaatan norma HAM oleh negara ASEAN sebagai cara untuk menyelamatkan permasalahan politik yang sudah ada sebelumnya (2013). Kedua, dimensi sifat (nature) dari pemakaian norma HAM. Pendekatan rasional kontemporer mendorong analisa terhadap halhal nonmaterial, termasuk norma, untuk bisa menjelaskan sifat kontemporer ASEAN (Davies, 2013).

\section{TARIK ULUR NILAI ASIA DAN KONSEP HAM GLOBAL DI ASEAN}

Perkembangan hak asasi manusia di ASEAN dimulai pada 1990-an, terutama setelah "Konferensi Dunia Hak Asasi Manusia" di Wina pada Juni 1993 (Ginbar, 2010). Tahun 1990 menjadi momentum penting bagi negara-negara ASEAN. Saat itu, beberapa anggota ASEAN berstatus sebagai negara yang baru merdeka. Kingsbury dkk (2008) berpendapat bahwa sebagai negara yang pernah mengalami penjajahan, ASEAN memiliki tantangan untuk menjadi negara yang demokratis. Salah satunya adalah pemerintah telah mendefinisikan dan mengakui hakhak sipil dan politik, namun belum tentu dilaksanakan dan dilindungi secara konsisten.

Perdebatan tentang nilai-nilai Asia dengan norma HAM universal (global human rights norms) bukanlah sesuatu yang asing. Banyak artikel yang sudah menganalisis hubungan kedua fenomena tersebut. 
Umumnya, para akademisi memandang dalam dua kategori. Pertama, mereka melihat nilai-nilai Asia sebagai bagian dari konstruksi awal demokratisasi di ASEAN. Premis ini bisa ditemukan dalam Kraft (2012), Freeman (1996), dan Katsumata (2009). Kedua, para peneliti fokus menganalisis bagaimana nilai-nilai Asia berdampak terhadap redefinition atau pemaknaan ulang konsep "universality" di Universal Declaration of Human Rights (UDHR). Analisa ini dapat dilihat di penelitian Mauzy (1997), Chan (2000), Freeman (2000), dan Ramcharan dan Ramcharan (2019). Secara singkat, studi-studi tersebut melihat bagaimana nilai-nilai Asia dibangun dan digunakan secara pragmatis oleh pemimpin ASEAN.

Nilai-nilai Asia yang didengungkan di awal tahun 1990 sangat berkaitan dengan perkembangan norma HAM di ASEAN. Tahun 1990-an merupakan masa genting yang di satu sisi terjadi pergolakan di internal negara-negara ASEAN dan di sisi lain, dunia internasional melalui Perserikatan Bangsa-Bangsa (PBB) juga sedang gencargencarnya mempromosikan HAM. Lee Kuan Yew menjadi orang pertama yang memperkenalkan konsep tersebut untuk menunjukkan jika masyarakat Asia berbeda dengan Barat (Freeman 1996). Hal ini dipertegas dengan Mahathir Mohamad yang menyatakan bahwa masyarakat Asia memiliki nilai-nilai komunal (common values) sebagai basisnya (Mahathir, 1995). Padahal, masyarakat yang dirujuk oleh Lee Kuan Yew adalah masyarakat Asia Timur yangmana memiliki karakter yang berbeda dengan Asia Tenggara (Freeman, 1996). Semangat "kebersamaan" itulah yang bertentangan dengan prinsip universalitas, termasuk hak perorangan (individual rights), yang diusung dalam UDHR oleh masyarakat Barat (western society).

Perdebatan antara nilai Asia dan norma HAM ini berkembang luas dan menghasilkan banyak analisa tentang alasan di belakang wacana ini. Alasan utama nilai-nilai Asia tidak setuju dengan prinsip universalitas dalam HAM karena HAM mengarusutamakan hak-hak 
individu yang berbeda dengan budaya di Asia. Sebagaimana Bangkok Post (1993 dalam Thabchumpon, 2008) menjelaskan bahwa masyarakat Asia lebih mementingkan kepentingan komunitas daripada masalah individu sebagai hal yang didengungkan masyarakat Barat. Lebih lanjut, Thabchumpon (2008) menjelaskan bahwa wacana pengarusutamaan pada nilai-nilai Asia fokus terhadap penolakan para pemimpin tentang konsep universalitas tersebut. Selain itu, beberapa pemimpin berdebat antara hak asasi manusia dan pertimbangan kedaulatan nasional (Thabchumpon, 2008). Alasan lainnya berupa pendekatan diferensiasi pada pelembagaan hak asasi manusia yang tidak bertemu dengan pendekatan yang berpusat pada masyarakat di Asia (Thabchumpon, 2008). Kesalahpahaman konsep HAM ada pada pembedaan antara hak yang sebagai dasar moralitas Barat dan tugas sebagai dasar moralitas Asia (Ghai, 1995 dalam Freeman, 1996). Namun, beberapa pihak mengungkapkan bahwa nilai-nilai Asia mengacu pada rezim otoriter (Katsumata, 2009; Leong, 2008; Avonius, 2008). Nilai-nilai Asia digunakan oleh pemimpin ASEAN sebagai cara untuk merepresi hakhak sipil dan politik masyarakat.

Kontestasi nilai-nilai Asia dan adopsi norma HAM menjadi medium atau alat tawar negara-negara ASEAN terhadap dunia internasional. Hal ini dapat dilihat dari isi Deklarasi Bangkok yang diadakan sebulan setelah Konferensi Wina 1993. Deklarasi Bangkok ditandai sebagai salah satu tindakan afirmasi positif dari negara-negara ASEAN untuk berkomitmen terhadap masalah hak asasi manusia. Namun, bagian budaya di deklarasi tersebut membuat para pemimpin ASEAN memikirkan ulang konsep universalitas yang merupakan bentuk penghormatan terhadap keanekaragaman budaya (Koskinen, 2008). Di sini, nilai-nilai Asia digambarkan sebagai hubungan budaya dan bukan politik (Kingsbury dkk, 2008). Sebenarnya, universalitas yang berada di bawah norma hak asasi manusia, sebagaimana diratifikasi banyak negara lain, merupakan representasi legitimasi untuk mengikuti 
standar internasional. Para pemimpin juga menjunjung tinggi dampak individualitas sebagai faktor pendorong kejahatan dengan kekerasan, kerusakan keluarga, tunawisma, dan penyalahgunaan narkoba (Thabchumpon, 2008). Lebih lanjut, Freeman (1996) menjelaskan bahwa norma hak asasi manusia universal adalah pelindung, bukan sebagai musuh keanekaragaman budaya. Pada akhirnya, pertentangan konsep universalitas dengan budaya ASEAN ini bermuara untuk meningkatkan posisi mereka dalam proses globalisasi (Ravindra, 1998 dalam Thanchumpon, 2008).

Dalam kaitannya dengan ekonomi, Katsumata (2009) berpendapat bahwa anggota ASEAN enggan untuk mereformasi asosiasi tetapi terjadi perubahan perilaku untuk menundukkan hak asasi manusia ketika mereka berada di bawah kekuatan eksternal yang kuat. Negara Barat (Amerika Serikat dan Eropa) memiliki kapasitas ekonomi dan materi yang lebih unggul dibanding dengan negara ASEAN. Posisi tersebut dimanfaatkan oleh negara Barat sebagai daya tawar untuk menekan ASEAN mengimplementasikan norma HAM (Katsumata 2009). Salah satu contohnya, negara Barat pernah mengancam menghentikan negosiasi perdagangan bebas dengan ASEAN jika tetap mendukung pemerintahan militer Nay Pyi Taw di Myanmar (Katsumata, 2009).

Tahun 1990-an juga menjadi awal krisis keuangan di ASEAN. Krisis keuangan Asia dimulai dengan jatuhnya nilai Baht Thailand pada 1997 yang kemudian dengan cepat menyebar ke seluruh kawasan (Davies, 2013). Sebagai dampaknya, orang mulai mempertanyakan arti kerja sama ekonomi regional yang tidak berdaya dalam menghadapi krisis (Davies, 2013; lihat juga Katsumata, 2009). Selain itu, orang-orang dan para pemimpin ASEAN juga mulai mempertanyakan nilai-nilai Asia yang selalu dijunjung tinggi tersebut. Sebenarnya, pertanyaanpertanyaan masyarakat tersebut sudah menunjukkan kontradiksi nilainilai Asia yang tidak membolehkan mengkritik para pemimpin mereka secara bebas. Sebaliknya, mereka diwajibkan untuk menghormati para 
pemimpin mereka sama halnya ketika mereka menghormati laki-laki sebagai kepala rumah tangga (Avonius, 2008). Akhir tahun 1999, nilainilai Asia semakin didengungkan, tetapi krisis keuangan juga semakin parah.

Negara-negara ASEAN mengadopsi hak asasi manusia sebagai strategi untuk "menyelesaikan masalah politik yang sudah ada sebelumnya, sifat dan arah proses reformasi regional yang telah berlangsung sejak 1997" (Davies, 2012). Singapura misalnya, ia bergantung pada wacana nilai-nilai Asia untuk mencegah reformasi politik yang mengusulkan pemerintahan demokratis (Leong, 2008). Singapura, sebagai negara dengan pertumbuhan ekonomi tercepat di kawasan ini, dikenal sebagai negara yang paling mendukung nilai-nilai Asia (Leong, 2008). Faktor ekonomi itulah yang menjadi posisi tawar mereka untuk menghadapi negara Barat yang menghadapi kemunduran dan penurunan ekonomi pada saat itu (Leong, 2008). Lebih jauh lagi, Singapura memecah nilai-nilai Asia dengan mengontekstualisasikannya dengan ledakan ekonomi mereka melalui "pendidikan, disiplin, penghormatan terhadap para tetua (termasuk pihak berwenang), konsensus mengenai konflik, serta komunitarianisme atas individualisme sebagai kunci kemajuan industri mereka" (Deyo, 1989 dikutip oleh Leong, 2008). Hak asasi manusia tidak memiliki tempat dalam bahasa seharihari dan repertoar konseptual di masyarakat Singapura (Leong, 2008). Namun, perlu dilihat dengan saksama bahwa orang yang mengartikulasikan serta memfungsikan nilai-nilai Asia berasal dari orang yang sama dengan yang memerintah Singapura selama kurang lebih 31 tahun, yaitu Lee Kuan Yew (Leong, 2008). Di sini, kita melihat pemimpin otoriter menggunakan nilai-nilai Asia untuk mempertahankan wacana publik, bahkan perilaku publik untuk menjaga perkembangan ekonominya. 
Ilustrasi lain bisa dilihat di Thailand. Nilai-nilai Asia digunakan oleh otoritas dan politisi sebagai retorika untuk mendukung agenda politik mereka (Thabchumpon, 2008). Negara ini telah meratifikasi UDHR sejak Desember 1948, namun mereka tidak meratifikasi International Convention on Civil and Political Rights (ICCPR) pada tahun-tahun berikutnya. Urgensi ratifikasi ICCPR muncul pada akhir tahun 1990 ketika masyarakat sipil Thailand secara terbuka memperdebatkan konsep saling terkait antara hak ekonomi, sosial, dan budaya dengan masalah konflik dalam hal pengelolaan sumber daya alam di negara tersebut (Thabchumpon, 2008). Tekanan semakin kuat ketika LSM pertama yang bergerak di isu HAM, yaitu Union for Civil Liberty (UCL) didirikan pada November 1973 yang dipengaruhi oleh gelombang demokratisasi di negara tersebut (Thabchumpon, 2008). Seperti efek bola salju, ada semakin banyak orang (termasuk akademisi dan kelas menengah) yang membahas HAM untuk mendorong proses demokratisasi dan membangun sistem politik yang efisien (Thabchumpon, 2008). Dari kasus Thailand, terlihat bahwa pihak berwenang dan politisi menggunakan konsep HAM untuk bereaksi dengan kondisi hak asasi manusia di negara itu, terutama dalam konflik dengan akar rumput juga.

\section{TAHUN 1991-1999 DI INDONESIA: NILAI-NILAI ASIA, HAM, DAN PERUBAHAN TUJUAN POLITIK}

\section{a. Nilai-Nilai Asia sebagai Strategi Politik: Program P4 Sebagai Representasi Nilai Asia dan Munculnya Lembaga-Lembaga HAM sebagai Tantangannya}

Implementasi nilai-nilai Asia terhadap limitasi kebebasan berekspresi di Indonesia sudah dimulai pemerintahan Soeharto sejak tahun 1980. Melalui TAP MPR II/MPR/1978 berjudul "Pedoman Penghayatan dan Pengamalan Pancasila (Ekaprasetya Pancakarsa)" 
dan kemudian disingkat sebagai $\mathrm{P} 4$, pemerintah menerapkan $\mathrm{P} 4$ di tempat kerja, sekolah, hingga universitas (Vickers dan Fisher, 1999). Program P4 ini berorientasi terhadap pembangunan nasional (Damanhuri \& Raharja, 2019). Program P4 diimplementasikan sebagai kebijakan dari pusat (top-down), terpusat, dan berbasis bahan ajar yang mengatur secara detail praktik Pancasila dalam kehidupan sehari-hari (Leigh, 1991 dalam Vicker dan Fisher, 1999). Jika ada orang yang tidak mengamalkan atau menentang Pancasila dalam kehidupan sehari-hari, ia dicap sebagai oposisi pembangunan dan diasingkan dalam asosiasi nasional (Damanhuri \& Raharja, 2019). Meskipun Pancasila dapat diartikan secara relatif terbuka dan pluralis, namun ia juga terbuka untuk penggunaan korporatif dan otoriter (Eldridge, 2002).

Lebih lanjut, doktrin integralis ini mengasumsikan persatuan antara pemerintah dan rakyat. Misalnya, dalam hal wacana pembangunan stabilitas ekonomi, pemerintah lebih menekankan musyawarah daripada perdebatan dan diskusi dengan masyarakat karena keputusan dan kepentingan berdasar konsensus diyakini mempercepat pertumbuhan ekonomi (Thompson, 2002). Dengan demikian, Pancasila menyangkal gagasan tentang hak individu atau kelompok terhadap negara, yang dipahami sebagai keluarga besar (Eldridge, 2002). Program kewarganegaraan ini berlandaskan pada Pancasila, ideologi resmi Indonesia pada saat itu. Bagi perempuan, definisi warga negara yang baik adalah tahu perannya sebagai istri dan ibu (Parker, 1992). Sedangkan bagi laki-laki, mereka harus tahu perannya sebagai pelayan agama yang baik dari negara (Parker, 1992). Sementara itu, program ini juga memiliki tujuan tersirat untuk menutup kemungkinan-kemungkinan ekspresi identitas alternatif di ranah lokal (Vickers and Fisher, 1999). Karakter implementasi program ini pun menarik. Pemerintah sering menggunakan kata "sosialisasi" untuk menggantikan musyawarah tradisional di masyarakat. Pada kenyataannya, sosialisasi berarti komunikasi satu arah dari pemilik 
otoritas kepada masyarakat (Avonius, 2008). Meski berjalan terlebih dahulu, program $\mathrm{P} 4$ ini memiliki esensi yang sama dengan nilai-nilai Asia, yakni menjunjung tinggi sifat komunal, lokalitas, dan cinta pada negara, serta pemimpin secara tidak langsung.

Dengan dalih untuk menjaga stabilitas negara dan kebebasan berpikir, implementasi program $\mathrm{P} 4$ memiliki dampak yang lebih luas terhadap masyarakat. Program P4 merupakan strategi pemerintah untuk mengimplementasikan nilai-nilai Pancasila dalam kehidupan sehari-hari, sekaligus menjadi alat propaganda untuk mendukung program pembangunan pemerintah (Damanhuri \& Raharja, 2019). Program P4 tidak hanya dijalankan secara masif di semua kalangan masyarakat. Lebih jauh, program P4 terintegrasi dalam kurikulum sekolah dimana semua kegiatan mengajar, organisasi, dan evaluasi sekolah diawasi langsung oleh pemerintah pusat (Damanhuri \& Raharja, 2019).

Nilai-nilai identitas yang berlandaskan Pancasila di sini dijadikan sebagai salah satu strategi pemerintah untuk menjaga stabilitas negara, sekaligus posisi politik pemerintah. Soeharto berupaya tidak menimbulkan perbedaan pendapat dalam kepemimpinannya (Hsien-Li, 2011). Cara menjaga stabilitas negara ini dibarengi dengan pembangunan ekonomi yang bisa meningkatkan standar hidup masyarakat. Namun di sisi lain, hak-hak masyarakat sangat dibatasi. Hak untuk berpartisipasi dalam politik adalah salah satu contohnya. Partai politik sangat dibatasi dan dikontrol pergerakannya (HsienLi, 2011; Eldridge, 2002). Dengan didukung oleh kekuatan militer, termasuk di ranah administrasi, kepemimpinan Soeharto dengan program P4-nya bisa diterima masyarakat. Strategi ini mirip dengan yang dilakukan Lee Kuan Yu di Singapura. Namun, strategi nilai-nilai Asia ini mulai goyah pada tahun 1990-an seiring dengan menguatnya gelombang kebebasan mengeluarkan pendapat, seperti yang di jamin dalam ICCPR, di ASEAN. 
Salah satu contoh menguatnya arus berpendapat adalah ketika masyarakat Indonesia melihat cara pemerintah menyelesaikan konflik di daerah-daerah. Instrumen militer yang digunakan pemerintah untuk mengatasi gerakan separatis terjadi di Dili (Timor Leste), Irian Jaya (Irian Barat), dan Aceh (Sumatra) sejak 1975 menjadi fokus perhatian banyak pihak. Dunia internasional mengecam pelanggaran HAM berat yang dilakukan oleh militer (Avonius, 2008). Misalnya, pembantaian lebih dari 200.000 orang di Timor-Timur (Hsien-Li, 2011) membuat dunia internasional dan masyarakat mengkritisi pemerintah (Avonius, 2008). Demi menenangkan publik, pemerintah akhirnya membentuk Komisi Penelitian Nasional (KPN) untuk menginvestigasi pelanggaran HAM yang ada (Avonius, 2008).

Selain kasus tersebut, publik juga meminta pemerintah untuk melakukan investigasi terhadap peristiwa Haur Koneng (1993) di Majalengka. Majalah Tempo edisi Oktober 1993 menjelaskan bahwa Haur Koneng diduga sebagai penganut aliran sesat oleh intel. Pada akhir Juli 1993, pengikut Haur Koneng dikepung oleh polisi dan tentara. Perlawanan pun tidak terelakkan dan memakan delapan orang korban. Padahal, menurut tim pencari fakta LBH di Bandung, mereka hanyalah korban fitnah yang dilatarbelakangi oleh sengketa tanah seluas dua hektar (Tempo, 1993). Sadar akan tekanan dan perhatian publik, Soeharto memperingatkan militer untuk lebih mengendalikan tekanan militer (Avonius, 2008). Keberanian berekspresi, seperti melakukan kecaman terhadap pemerintah, membuat Soeharto memikirkan ulang strategi politiknya.

Munculnya lembaga-lembaga sipil HAM juga menjadi salah satu tanda kemunduran nilai-nilai Asia di Indonesia. Tantangan nilai-nilai Asia di Indonesia pada saat itu berasal dari kalangan masyarakat sipil yang semakin vokal menyuarakan keadilan. Perkembangan ekonomi dari tahun 1960-1970 telah meningkatkan akses pendidikan kelas menengah pada saat yang bersamaan (lihat Hsien-Li, 2011; Eldridge, 
2002). Mahasiswa, jurnalis, pengacara, dan profesi lainnya bergabung dan membentuk organisasi masyarakat sipil yang fokus mengkritisi Dwi Fungsi ABRI di pemerintahan, ketimpangan upah, hingga peristiwa pelanggaran HAM berat, seperti di Dili, Aceh, dan Papua (HsienLi, 2011). Organisasi masyarakat sipil mulai bermunculan, seperti International Forum for Indonesian Development (INFID), Solidaritas Perempuan, Kalyanamitra, dan Yayasan Lembaga Bantuan Hukum Indonesia (YLBHI) (Hsien-Li, 2011). Mereka mengumpulkan buktibukti pelanggaran HAM yang dilakukan oleh pemerintah dan agenagennya. Tahun 1990-an menjadi tahun yang panjang bagi Soeharto. Ketika Soeharto memperketat aturan dan melakukan pelanggaran HAM atas nama Pancasila, masyarakat Indonesia semakin gencar menentang kesewenang-wenangan yang ada (Hsien-Li, 2011).

Tekanan dari dunia internasional untuk melembagakan HAM di Indonesia membuat pemerintah memikirkan ulang strategi politiknya, dimana action-identity gap semakin kentara terlihat. Awal tahun 1990an di Indonesia merupakan salah satu periode penting dalam wacana hak asasi manusia karena tekanan internasional untuk pemerintahan Soeharto meningkat (Avonius, 2008). Pembantaian di Dili, ibu kota Timor-Timur, pada tahun 1991 menarik perhatian internasional, termasuk organisasi hak asasi manusia. Pemerintah Indonesia menunjukkan sikap yang ambivalen di tengah tekanan yang semakin kuat. Sebagai contoh, di satu sisi, pemerintah Indonesia akhirnya bersedia menerima pemantauan dari PBB dan LSM internasional, seperti Amnesty International (Avonius, 2008). Di sisi lain, kebijakan pemerintah untuk memperkuat militer semakin jelas. Misalnya, keputusan Menteri tahun 1986 yang menginzinkan militer melakukan intervensi terhadap kekacauan industri, khususnya pada demonstrasi buruh (Ford, 2012 dalam Avonius, 2008). Pelembagaan norma HAM tidak serta-merta menghilangkan nilai-nilai Asia dalam pemerintahan. 
Pemerintah masih mencoba mengontrol diskursus HAM dari internasional dengan memperkuat instrumen politiknya, yakni militer.

Contoh lain dalam menjaga citra sebagai pemerintahan yang mengadopsi norma HAM, sekaligus untuk meningkatkan posisi tawar di komunitas internasional, pemerintah Indonesia membentuk Komisi Nasional Hak Asasi Manusia (Komnas HAM) pada tahun 1994 (Avonius, 2008). Bagi pemerintah, Komnas HAM menjadi kedok atau display bagi forum HAM internasional. Namun, berkat keberanian orang-orang yang ditunjuk menjadi komisioner pertamanya, organisasi ini bekerja di luar prediksi pemerintah dan menjadi salah satu alat yang berpengaruh terhadap perjuangan HAM di Indonesia (Avonius, 2008). Laporan pertama Komnas HAM tentang kasus pembunuhan Marsinah, seorang aktivis buruh dari Sidoarjo, Jawa Timur, menunjukkan kesalahan otoritas negara dalam menangani kasus tersebut. Laporan tersebut menjadi sejarah bagi Indonesia karena berani meminta pertanggungjawaban militer atas kekerasan warga sipil (Honna, 2005 dalam Avonius, 2008). Kebebasan berpendapat dan berpikir yang muncul di kalangan masyarakat sipil telah membawa perubahan yang signifikan terhadap strategi politik pemerintah Soeharto.

\section{b. Norma HAM Sebagai Instrumen Politik: Menelisik Dimensi Waktu dan Karakter Norma HAM di Masa Transisi}

Kondisi regional yang semakin terbuka terhadap diskusi isuisu sosial membuat norma-norma HAM ikut dipertimbangkan oleh otoritas Indonesia. Sejak akhir 1980-an, kebijakan tentang keterbukaan terhadap isu-isu pelanggaran HAM menjadi pengetahuan umum dan didorong oleh banyak aktor domestik maupun internasional (Avonius, 2008). Antara tahun 1997 hingga 2003, negara-negara ASEAN aktif mendiskusikan tentang arah dan karakter perubahan visi organisasi. Diskusi yang terjadi membahas integrasi kepentingan isu sosial secara umum dan tidak secara khusus membahas tentang perkembangan 
HAM (Davies, 2013). Dalam perumusan visi ASEAN untuk 2020 di tahun 1997, negara-negara tersebut menggarisbawahi pentingnya hak-hak individual dan tanggung jawab sosial sebagai landasan dari pembangunan yang adil dan beradab. Namun, pada Bali Concord II, yang merupakan hasil Konferensi Tingkat Tinggi (KTT) ASEAN ke 7, tidak menyebutkan HAM sama sekali (Davies, 2013). Artinya, pandangan negara-negara ASEAN tentang norma HAM pada saat itu masih sama, yakni melihat norma HAM sebagai salah satu alat tawar. Hal ini sejalan dengan argumen Davies (2013) yang menjelaskan jika proses Reformasi di ASEAN, bersamaan dengan waktu munculnya hak asasi manusia di dalamnya, telah mendukung atau memperkuat pilihan rasional aktor.

Mengacu pada argumen Davies (2013) bahwa peran Komnas HAM dapat menjadi gambaran keadaan kontemporer perkembangan norma HAM di Indonesia pada waktu itu. Pembentukan Komnas HAM merupakan salah satu upaya pemerintah untuk mengubah keadaan diplomasi internasionalnya (Eldridge, 2002). Namun, jajaran Komnas HAM menggunakan norma bukan hanya sebagai strategi atau display. Mereka memberikan laporan kritis tentang pelanggaran HAM pemerintah dan berkontribusi terhadap peningkatan kesadaran HAM di masyarakat (Eldridge, 2002). Bersamaan dengan merebaknya tekanan internasional, termasuk komitmen di atas regional ASEAN melalui Deklarasi Bangkok, di Indonesia telah terjadi proses perubahan. Hal ini bisa dilihat baik dari sisi pemerintah maupun Komnas HAM dalam menggunakan norma HAM. Strategi awal pemerintah untuk menjaga posisi politik mereka dengan menggunakan norma HAM mulai tidak relevan lagi dengan keadaan kontemporer waktu itu. Perkembangan nasional, khususnya di bidang pendidikan dan sosial yang mengubah persepsi masyarakat tentang isu HAM, bisa menjadi faktor pendorong yang sama efektifnya dengan komunitas internasional. 
Seiring dengan berkembangnya kesadaran hak sipil dan politik, pertengahan tahun 1990-an menjadi tahun penuh kontestasi nilai Asia dan norma HAM di Indonesia. Prinsip keterbukaan yang sedang didengungkan saat itu tidak mengubah karakter militer Indonesia yang justru semakin opresif. Koran Tempo dibredel oleh militer pada tahun 1994 karena memberitakan rencana pemerintah untuk membeli peralatan perang dari Jerman Timur (Avonius, 2008). Sebagai akibatnya, terjadi demonstrasi besar-besaran selama dua minggu untuk menyuarakan pembatasan hak berekspresi oleh pemerintah. Ketika kelompok masyarakat sipil tumbuh dan semakin vokal, perpecahan pun mulai terjadi di dalam pemerintah, khususnya berasal dari Komnas HAM. Hal ini membuat pemerintah semakin sulit mengontrol suarasuara perbedaan yang ada (Avonius, 2008). Pada tahun 1997, krisis ekonomi yang sangat berpengaruh terhadap hak dasar ekonomi masyarakat menambah perdebatan tentang keamanan negara antara masyarakat sipil dan militer yang sebelumnya sudah semakin memanas. Dampaknya, akuntabilitas pemerintah semakin dipertanyakan karena tidak bisa mengatasi krisis yang mengakibatkan pengangguran dan kelaparan meningkat.

Keengganan pemerintah untuk mengikuti adopsi norma HAM berdampak pada kejatuhan Soeharto pada Mei 1998, yang setelah menjabat lebih dari 30 tahun. Masyarakat mengadakan demonstrasi besar-besaran untuk menumbangkan rezim Orde Baru atau dikenal dengan Reformasi (Avonius, 2008). Pada saat itu, isu HAM semakin berkembang kepada hak ekonomi, penghidupan yang layak, dan pengentasan kemiskinan ${ }^{3}$ (Eldridge, 2002). Reformasi menjadi keputusan yang logis jika mempertimbangkan konteks pada saat itu, yakni menguatnya arus hak sipil, politik, dan ekonomi di masyarakat (lihat juga Mollet, 2018). Kebangkitan masyarakat sipil

3 Isu-isu hak ekonomi ini tercantum dalam artikel 7 dan 11 International Convenant on Economic, Social, and Cultural Rights (ICESCR). 
hasil pembangunan pendidikan pada masa Soeharto yang dibangun sejak tahun 1980-an, berkontribusi terhadap kejatuhan Soeharto (Thompson, 2004). Program P4 yang digalakkan Soeharto tidak mampu membungkam kekuatan masyarakat sipil. Di sini, konteks waktu tampak menjadi dasar rasionalisasi dari sebuah tujuan politik, yakni akomodasi norma HAM sepenuhnya.

Pasca Soeharto, pemerintah Indonesia melakukan beberapa kemajuan dalam hal institusionalisasi norma HAM. Pada tahun 1999, Indonesia memiliki Undang-Undang tentang Hak Asasi Manusia (UU 39/1999) yang menjelaskan tentang kebebasan berekspresi, berpendapat, baik lisan maupun tertulis di media cetak dan elektronik (Avonius, 2008). Lebih jauh lagi, kebebasan berpendapat ini dibarengi dengan kewajiban warga negara untuk tetap mempertimbangkan nilainilai agama, etika, keterbukaan, kebaikan bersama, serta persatuan bangsa. Produk hukum lain yang turut mendorong HAM di Indonesia adalah UU Pers yang baru (UU 40/1999) (Avonius, 2008). Dorongan Presiden Habibie untuk mempercepat pembahasan UU ini dianggap telah meningkatkan kebebasan pers di Indonesia (Avonius, 2008 dan Eldridge, 2002). Kedua Undang-Undang ini menjadi capaian tersendiri bagi institusionalisasi norma HAM di Indonesia. Perubahan waktu adopsi norma HAM pada tahun 1999 memengaruhi nature atau karakter penggunaan norma tersebut. Salah satu konsekuensi dari Reformasi adalah norma HAM tidak digunakan sebatas semboyan. Tetapi, norma tersebut mulai diinstitusionalisasi demi memberikan kepastian hukum kepada masyarakat.

Karakter penggunaan norma HAM pada pemerintah pasca Reformasi ini pun masih dirasa setengah-setengah. Vicker dan Fisher (1999) berpendapat bahwa ada kemiripan antara pemerintah Orde Baru dengan pemerintah pasca Reformasi, dimana penguasa tidak pernah mengurangi dominasi status quo mereka terhadap rakyat. Hal tersebut dapat dilihat dalam kebijakan KUHP. Garansi kebebasan pers 
pada UU 40/1999 nyatanya tidak benar-benar bekerja. Alasannya, pemerintah juga mengatur kebebasan pers sampai tahap tertentu melalui penggunaan pasal-pasal pencemaran nama baik KUHP terhadap media bebas dan aktivis HAM (Avonius, 2008). Argumen Davies tentang penggunaan norma HAM sebagai instrumen politik masih terasa pada pemerintahan pasca Reformasi. Di sini, upaya menginstitusikan norma HAM lebih berfungsi sebagai kamuflase yang belum terwujud dalam perilaku pemerintah (Davies, 2013).

Kasus Indonesia menunjukkan bagaimana otoritas menggunakan konsep hak asasi manusia untuk menghadapi krisis dan tekanan, baik dari internasional maupun internal. Selain itu, dari kasus-kasus tersebut juga menunjukkan bahwa nilai-nilai Asia berubah menjadi hambatan serius karena menciptakan nepotisme, kronisme, dan konsensus yang mengarah pada politik yang korup, kekerasan sebagai bentuk penghormatan terhadap otoritas, dan keadaan usaha yang tidak kondusif (The Economist, 1998 dalam Leong, 2008). Argumen ini juga mendukung pemikiran Amartya Sen yang menekankan bahwa alih-alih mendukung kebebasan, nilai-nilai Asia cenderung memperhatikan ketertiban dan disiplin yang diperlukan dalam konteks regional itu sendiri (1996 dalam Thabchumpon, 2008). Lebih jauh lagi, negara-negara ASEAN (termasuk Indonesia) tersebut mengalami xenophobia yang berarti "gagasan dan lembaga asing dianggap sebagai agen penganggu yang menginfeksi dan mencemari penduduk lokal" (Kingsbury dll, 2000 dikutip Leong, 2008). Berbicara tentang keunikan budaya, negara-negara tersebut sebenarnya takut terhadap perubahan yang akan terjadi dalam masyarakat mereka, terutama yang berkaitan dengan gerakan sosial yang dapat memengaruhi posisi mereka. Tetapi, seperti yang terlihat di Indonesia dan di Thailand, konsep hak asasi manusia tersebar dalam banyak cara yang dapat menantang status quo para pemimpinnya. 


\section{KESIMPULAN}

Menjawab rumusan masalah yang sudah disinggung di awal, tulisan ini menunjukkan nilai-nilai Asia dan norma HAM pada tahun 1990-an di Indonesia yang digunakan sebagai sebuah instrumen dan tujuan politik. Teori Davies tentang teori pilihan rasional terlihat pada masa Soeharto. Sejak tahun 1980-an, nilai-nilai Asia digunakan untuk mengekang kebebasan berpendapat melalui program P4. Nilai-nilai Asia sebagai instrumen politik dapat menjaga stabilitas pemerintahan untuk waktu tertentu. Namun, seiring dengan terjadinya perkembangan regional dan internasional, nilai-nilai Asia mulai mendapat tantangan dan norma HAM menjadi tujuan politik baru. Tekanan semakin keras ketika masyarakat sipil yang berpendidikan, yang merupakan hasil pembangunan dan kemajuan ekonomi, menggunakan norma HAM sebagai tujuan politik. Pada tahap ini, norma HAM digunakan pemerintah Orde Baru sebagai tujuan politik, sekaligus mempertahankan posisinya. Atau mengikuti argumen Davies, norma HAM digunakan untuk menyelesaikan masalah-masalah yang ada dalam pemerintahan ASEAN tanpa benar-benar menerapkannya secara konsisten. Untuk Indonesia, pembatasan hak sipil dan politik menjadi salah satu masalah mendasar yang bisa diselesaikan dengan menginstitusikan norma HAM, namun tanpa pernah menuntaskan kasus-kasus pelanggaran HAM.

Penggunaan norma sebagai instrumen dalam tulisan ini menjawab kesenjangan dalam studi pustaka tentang action-identity gap. Pemerintah Indonesia mengadopsi HAM dengan tujuan tertentu, yakni untuk mengamankan otoritas pemerintah dan menyelesaikan konflik internal yang ada. Dengan demikian, perbedaan perilaku dalam menyikapi pelanggaran HAM di ranah regional dan nasional bisa dipahami dari tujuan politik mereka pada waktu itu. Pada tahap ini, tulisan ini memperkuat argumen Davies tentang pentingnya melihat dimensi waktu pelaksanaan nilai Asia dan norma HAM di ASEAN. 
Kondisi dan konteks pada tahun 1990-an bisa membantu menjelaskan karakter penggunaan norma sebagai instrumen politik. Analisa tersebut menunjukkan bahwa pendekatan rasional bisa memberikan penjelasan tentang hubungan keterlibatan pemerintah Soeharto dengan nilainilai Asia dan norma HAM. Bahwa action-identity gap yang terjadi di ASEAN (termasuk di Indonesia) dipengaruhi oleh tujuan politik dari masing-masing aktor, terutama dari pihak penguasa. Namun di luar dugaan pemerintah, dari sisi masyakarat sipil, norma HAM sebagai instrumen mampu membentuk identitas dan perilaku kritis terhadap penegakan HAM. 


\section{REFERENSI}

Acharya, A. (2005). Do Norms and Identity Matter? Community and Power in Southeast Asia's Regional Order. The Pacific Review, Volume 18 (1), 95-118. DOI: https:// doi.org/10.1080/09512740500047199.

Asplund, K. (2009). Resistance to Human Rights in Indonesia: Asian Values and Beyond. Asia-Pacific Journal on Human Rights and the Law, Volume 10 (1), 27-47. doi: https://doi.org/10.1163/138819009X12589762582538.

Avonius, Leena. (2008). From Marsinah to Munir: Grounding Human Rights in Indonesia. In Avonius, Leena., and Kingsburry, Damien (Editor). 2008. Human Rights in Asia: A Reassessment of the Asian Values Debate. New York: Palgrave Macmillan.

Bangkok Post Economic Review Year-End. (2006). http://bangkokpot.net/ yearend2006/ page10.html. Diakses pada 15 Mei 2007.

Chan, Joseph. (2000). Thick and Thin Accounts of Human Rights: Lessons from the Asian Values Debate. Dalam Jacobsen, M., and Bruun, Ole. Human Rights and Asian Values: Contesting National Identities and Cultural Representations in Asia. London: Curzon and Nordic Institute of Asian Studies (58-73).

Chong, T. (2002). Asian Values and Confucian Ethics: Malay Singaporeans' Dilemma. Journal of Contemporary Asia, 32(3), 394-406.

Dahl, Robert A. (1989). Democracy and its Critics, New Haven, CT: Yale University Press.

Damanhuri, Hudjolly., \& Reza Mauldy Raharja. (2019). The Transformation of Character Ideology of Pancasila Through Education. Saudi Journal of Humanities and Social Sciences, 274-278. https://pdfs.semanticscholar.org/cb29/08d7b71d47af4294 e4088d06e2fc3311e180.pdf. Diakses pada 1 Juni 2019.

Davies, Mathew. (2013). ASEAN and Human Rights Norms: Constructivism, Rational Choice, and the Action-Identity Gap. International Relations of the Asia-Pacific. Vol. 13, 2013, 207-231. https://academic.oup.com/irap/articleabstract/13/2/207/8374 31. DOI:10.1093/irap/lct002. Diakses pada 1 Juni 2019. 
Deyo, Frederic. (1989). Beneath the Miracle: Labour Subordination in the New Asian Industrialism. Berkeley: University of California Press.

Eldridge, Philip. "Human Rights in Post-Suharto Indonesia." The Brown Journal of World Affairs 9, No. 1 (2002): 127-139.

Freeman, Michael. (1996). Human Rights, Democracy, and Asian Values. The Pacific Review, Vol 9 No. 3, 352-366. Published online on April 3rd, 2007. https://www.tandfonline.com/doi/abs/10.1080/09512749608719191. DOI: 10.1080/09512749608719191. Diakses pada 1 Juni 2019.

Ford, Michelle. (2003). NGO as Outside Intellectual: A History of Non-Governmental Organisations' Role in the Indonesian Labour Movement. E-publication of PhD thesis at the University of Wollongong. https://ro.uow.edu.au/theses/150/. Diakses pada 1 Juni 2019.

Freeman, Michael. (2000). Universal Rights and Particular Culture. Dalam Jacobsen, M., and Bruun, Ole. Human Rights and Asian Values: Contesting National Identities and Cultural Representations in Asia. London: Curzon and Nordic Institute of Asian Studies (43-57).

Ghai, Yash. (1995). Asian Perspectives on Human Rights. Dalam James T.H. Tang (ed.) Human Rights and International Relations in the Asia-Pacific Region, London: Pinter, 54-67.

Ginbar, Yuval. (2010). Human Rights in ASEAN: Setting Sail or Treading Water? Human Rights Law Review, Vol. 10 No. 3, 2010, 504-518. https://academic.oup.com/hrlr/ article-abstract/10/3/504/637270. DOI:10.1093/hrlr/ngq024. Diakses pada 1 Juni 2019.

Honna, Jun. (2005). Military Politics and Democratization in Indonesia. London, New York: Routledge.

Hsien-Li, Tan. (2011). The ASEAN Intergovernmental Commission on Human Rights: Institutionalising Human Rights in Southeast Asia. New York: Cambridge University Press. 
Jones, D.M. and M.L.R. Smith (2007). Constructing Communities: the curious case of East Asian Regionalism. Review of International Studies, Volume 33(1), 165-186.

Katsumata, H. (2009). ASEAN and Human Rights: Resisting Western Pressure or Emulating the West? The Pacific Review, 22(5), 619-637. https://www. tandfonline.com/doi/ abs/10.1080/09512740903329731. Diakses pada 1 Juni 2019.

Kingsbury, Damien., Eric Loo, and Patricia Payne (eds.). (2000). Foreign Devils and Other Journalists. Clayton, Victoria: Monash Asia Institute.

Kraft, Joseph. S. (2001). Human Rights, ASEAN, and Constructivism: Revisiting the "Asian Values" Discourse. Philippine Political Science Journal, Volume 22: 45, 33-54, DOI: 10.1080/01154451.2001.9754224.

Koskinen. Päivi. (2018). Asian Values, Gender, and Culture-Specific Development. In Avonius, Leena., and Kingsburry, Damien (Editor). 2008. Human Rights in Asia: A Reassessment of the Asian Values Debate. New York: Palgrave Macmillan.

Kydd, A.H. (2008). Methodological Individualism and Rational Choice. Dalam Christian Reus-Smit and Duncan Snidal (eds). The Oxford Handbook of International Relations. Oxford: Oxford University Press.

Leigh, Barbara. (1991). Making the Indonesian State: The Role of School Texts. RIMA, Volume 25, No. 1, 1991: 17-43.

Leong, Laurance Wai-Teng. (2008). From Asian Values to Singapore Exceptionalism. Dalam Avonius, Leena., and Kingsburry, Damien (Editor). 2008. Human Rights in Asia: A Reassessment of the Asian Values Debate. New York: Palgrave Macmillan.

Mahathir, Mohamad (1995). Let's Have Mutual Cultural Enrichment. New Straits Times 16 March, 10-11. 
Mauzy, Diane K. (1997). The Human Rights and “Asian values” Debate in Southeast Asia: Trying to Clarify the Key Issues. The Pacific Review, Volume 10 (2), 210-236, DOI: https://doi.org/10.1080/09512749708719218.

Mollet, Julius Ary (2018), Corruption and Asian Value's in Indonesia: The Case of the Suharto Family Business. Journal of Social and Political Sciences, Vol. 1, No. 2, 314 -325. DOI: 10.31014/aior.1991.01.02.22.

Nurhadi. (2019). Kronologi Insiden Asrama Mahasiswa Papua Surabaya Menurut Polisi. Nasional Tempo.co. 20 Agustus 2019. https://nasional.tempo.co/ read/1238416/ kronologi-insiden-asrama-mahasiswa-papua-surabayamenurut-polisi/full\&view =ok. Diakses pada 1 Juni 2019.

Parker, Lynette. (1992). The Creation of Indonesian Citizens in Balinese Primary Schools. RIMA. Volume 26, No. 1, 1992: 42-70.

Ravindran, D. J. (1998). Human Rights Praxis: A Resource Book for Study, Action, and Reflection. Bangkok: Union for Civil Liberty.

Schimmelfennig, F. (2000). International Socialization in the New Europe: Rational Action in an Institutional Environment. European Journal of International Relations, Volume 6 (1), 109-140.

Sen, Amartya. (1996). Our Culture, Their Culture. The New Republic, April 1, 1996.

Setiawan, R. (2019). Isi Pasal Bermasalah UU KPK No.19/2019 yang Sudah Berlaku. Tirto.id, 21 Oktober 2019. https://tirto.id/isi-pasal-bermasalahuu-kpk-no192019-yang-sudah-berlaku-ej8o. Diakses pada 1 Juni 2019.

Tempo. (1993). Mereka Membela Diri: Menurut Tim Pencari Fakta dari Lembaga Bantuan Hukum (LBH) Bandung, Pengikut Haur Koneng Bukan Penganut Aliran Sesat, Berbeda dengan Laporan Selama Ini? Majalah.Tempo.com, Edisi 9 Oktober 1993. https://majalah.tempo.co/read/nasional/2962/ mereka-membela-diri. Diakses pada 1 Juni 2019. 
Thabchumpon, Naruemon. (2008). Human Rights in Thailand: Rhetoric of Substance on "Asian values". In Avonius, Leena., and Kingsburry, Damien (Editor). 2008. Human Rights in Asia: A Reassessment of the Asian Values Debate. New York: Palgrave Macmillan.

The Economist. (1998). Asian Values Revisited: What Would Confucius Say Now? Diakses pada 1 Juni 2019.

Thomas, D.C. (2001). The Helsinki Effect: International Norms, Human Rights, and the Demise of Communism. Princeton, NJ: Princeton University Press.

Thompson, Mark R. (2004) Pacific Asia after "Asian Values": Authoritarianism, Democracy, and "Good Governance", Third World Quarterly, 25: 6, 10791095, DOI: $10.1080 / 0143659042000256904$.

Ulum, M.B., dan Hamida N.A. (2018). Revisiting Liberal Democracy and Asian Values in Contemporary Indonesia. Constitutional Review, Vol. 4 No. 1, May 2018. Doi: https://doi.org/10.31078/consrev415.

VICKERS, A., \& FISHER, L. (1999). Asian Values in Indonesia? National and Regional Identities. Sojourn: Journal of Social Issues in Southeast Asia, Volume 14 (2), 382-401. www.jstor.org/stable/41057002. Diakses pada 1 Juni 2019.

Wendt, A. (1994). Collective Identity Formation and the International State. American Political Science Review, Volume 88 (2), 384-396. 


\section{ACKNOWLEDGEMENT:}

Naskah ini merupakan pengembangan salah satu tugas kuliah di Institute of Human Rights and Peace Studies (IHRP), Mahidol University. Kemudian, saya ingin mengucapkan terima kasih kepada mentor saya, Desi Rahmawati. Naskah ini tidak akan selesai tanpa bimbingan dan diskusi dengannya. Terakhir, saya juga ingin berterima kasih kepada blind reviewer dan Tim Mentoring Penulisan Jurnal yang telah membantu proses penulisan jurnal ini. 